\title{
Environmental indicator for effective control of COVID-19 spreading
}

\author{
Xinbo Lian", Jianping Huang ${ }^{1,2, *}$, Li Zhang ${ }^{1}$, \\ Chuwei Liu ${ }^{1}$, Xiaoyue Liu' ${ }^{1}$, Lina Wang ${ }^{3}$ \\ ${ }^{1}$ Collaborative Innovation Center for Western Ecological Safety, College of \\ Atmospheric Sciences, Lanzhou University, Lanzhou, 730000, China. \\ ${ }^{2}$ CAS Center for Excellence in Tibetan Plateau Earth Sciences , Beijing 100101,China. \\ ${ }^{3}$ Gansu Province Environmental Monitoring Center, Lanzhou, 730000, China.
}

Corresponding Author :

Dr. Jianping Huang ( hjp@1zu.edu.cn ) 


\begin{abstract}
Recently, a novel coronavirus (COVID-19) has caused viral pneumonia worldwide, spreading to more than 200 countries, posing a major threat to international health. To prevent the spread of COVID-19, in this study, we report that the city lockdown measure was an effective way to reduce the number of new cases, and the nitrogen dioxide $\left(\mathrm{NO}_{2}\right)$ concentration can be adopted as an environmental lockdown indicator. In China, after strict city lockdown, the average $\mathrm{NO}_{2}$ concentration decreased $55.7 \%$ (95\% confidence interval (CI): $51.5-59.6 \%)$ and the total number of newly confirmed cases decreased significantly. Our results also indicate that the global airborne $\mathrm{NO}_{2}$ concentration steeply decreased over the vast majority of COVID-19-hit areas based on satellite measurements. We found that the total number of newly confirmed cases reached an inflection point about two weeks after the lockdown. The total number of newly confirmed cases can be reduced by about $50 \%$ within 30 days of the lockdown. The stricter lockdown will help newly confirmed cases to decline earlier and more rapidly. Italy, Germany and France are good examples. Our results suggest that $\mathrm{NO}_{2}$ satellite measurement can help decision makers effectively monitor control regulations to reduce the spread of COVID-19.
\end{abstract}


medRxiv preprint doi: https://doi.org/10.1101/2020.05.12.20099804; this version posted July 27, 2020. The copyright holder for this preprint (which was not certified by peer review) is the author/funder, who has granted medRxiv a license to display the preprint in perpetuity.

It is made available under a CC-BY-NC 4.0 International license.

\section{1. Introduction}

Large-scale COVID-19 viral pneumonia through human-to-human transmission poses a

3 severe and acute public health emergency (Huang et al., 2020a; Li et al., 2020). As the epidemic

4 worsened, most countries imposed city lockdown and quarantine measures to reduce

5 transmission to control the epidemic. The Chinese government has gradually implemented a

6 city-wide quarantine of Wuhan and several surrounding cities as of 23 January, flights and trains

7 to and from Wuhan have been suspended, and public transport has been halted (Cyranoski et al.,

8 2020; Wu et al., 2020). The entire northern Italy was quarantined since 9 March 2020, and three

9 days later the government extended it to the whole country (Paterlini, 2020). The Spanish

10 government declared a 15-day national emergency, starting on 15 March (Legido-Quigley et al.,

11 2020). In the United States, on 19 March, California became the first state to order a lockdown

12 (Baccini et al., 2020). In Germany, since 18 March, 16 states have closed, public gatherings of

13 more than two people have been banned and most shops except supermarkets and pharmacies

14 have closed (Dehning et al., 2020). On 23 March, the British government announced a new

15 nationwide restriction allowing residents to only venture outside when absolutely necessary, e.g.,

16 to work, buy necessities (Iacobucci, 2020).

17 The worldwide lockdown, which was imposed to stop the spread of the novel coronavirus,

18 not only caused an economic downturn but also appeared to result in cleaner air in urban areas

19 usually heavily affected by pollution (Lian et al., 2020; Schiermeier, 2020). The most important

20 measure of the lockdown policy was the reduction of traffic and control personnel flow, and

21 traffic pollution is an important factor influencing air quality and public health. Vehicle exhaust

22 and evaporation emissions are the main emission sources of ozone and secondary particle 
medRxiv preprint doi: https://doi.org/10.1101/2020.05.12.20099804; this version posted July 27, 2020. The copyright holder for this preprint (which was not certified by peer review) is the author/funder, who has granted medRxiv a license to display the preprint in perpetuity.

It is made available under a CC-BY-NC 4.0 International license.

23 precursors near the ground in cities and regions (Zhou et al., 2019; Yuan et al., 2013), and the

24 spatial variation of nitrogen dioxide $\left(\mathrm{NO}_{2}\right)$, fine particulate matter $\left(\mathrm{PM}_{2.5}\right)$ and black carbon $(\mathrm{BC})$

25 may also be significant affected by traffic flow density (Clougherty et al., 2013). A study in Los

26 Angeles showed that nitrogen oxides $\left(\mathrm{NO}_{\mathrm{x}}\right)$ were identified as a source of pollution for light

27 vehicles, with $\mathrm{NO}_{2}, \mathrm{NO}_{\mathrm{x}}$, carbon dioxide $\left(\mathrm{CO}_{2}\right), \mathrm{BC}$, and fine particle number $\left(\mathrm{PN}_{\text {fine }}\right)$ identified

28 as diesel exhaust sources (Tessum et al., 2018; Fan et al., 2018). In South Korea, source analysis

29 studies have shown that there is a high correlation between estimated traffic volume and $\mathrm{NO}_{2}$

30 concentration (Kim et al., 2015). $\mathrm{NO}_{2}$ levels can be used as a proxy for exposure to

31 traffic-related composite air pollution and to assess the impact of scenarios designed to reduce

32 traffic-related emissions (Brnnum-Hansen et al., 2018; Johansson et al., 2017).

33 In this report, we study the parameters of environmental indicators for city lockdown. Using

34 the automatic ground detection data and satellite data to analyze the trend of lockdown and the

35 total confirmed new cases in major cities in China, and using satellite data to further study the

36 impact of lockdown on virus transmission in countries mainly severely affected by the epidemic,

37 in order to help policymakers to formulate effective control measures to reduce the spread of

38 COVID-19.

\section{Data and measurement}

41 The ground observation daily data were provided by the China National Environmental

42 Monitoring Centre (http://www.cnemc.cn/). The data from January 24, 2020, to February 23,

43 2020, are selected as the representative data after the lockdown in Hubei, and the data from 
medRxiv preprint doi: https://doi.org/10.1101/2020.05.12.20099804; this version posted July 27, 2020. The copyright holder for this preprint (which was not certified by peer review) is the author/funder, who has granted medRxiv a license to display the preprint in perpetuity.

It is made available under a CC-BY-NC 4.0 International license .

44 December 24, 2019, to January 23, 2020, are selected as the representative data before the

45 lockdown (Fig. 1). The $\mathrm{NO}_{2}$ ground observation data of China is from 1 January 2020 to 1

46 March 2020. The average concentration of major cities with severe epidemic diseases was

47 selected as the representative of $\mathrm{NO}_{2}$ concentration of China, including Wuhan, Nanchang,

48 Guangzhou, Hangzhou, Changsha, Beijing, Shanghai, Hefei and Zhengzhou (Fig. 3). All

49 monitoring instruments of the air quality automatic monitoring system operate automatically 24

$50 \mathrm{~h}$ a day. The monitoring items are $\mathrm{PM}_{2.5}, \mathrm{PM}_{10}, \mathrm{SO}_{2}, \mathrm{NO}_{2}$, and $\mathrm{CO}$. The automatic monitoring of

$51 \mathrm{PM}_{2.5}$ and $\mathrm{PM}_{10}$ adopts the micro-oscillating balance method and the $\beta$-absorption method,

52 respectively (ambient air quality standards, GB 3095-2012). $\mathrm{SO}_{2}$ was determined by the

53 ultraviolet fluorescence method, $\mathrm{NO}_{2}$ by the chemiluminescence method, $\mathrm{CO}$ by the

54 nondispersion infrared absorption method and gas filter correlation infrared absorption method.

55 This paper adopted the level 3 daily global gridded $\left(0.25^{\circ} \times 0.25^{\circ}\right)$ nitrogen dioxide product

56 (OMNO2d) provided by the Ozone Monitoring Instrument (OMI) onboard the Aura satellite as

57 the daily $\mathrm{NO}_{2}$ data, which can be obtained from GES DISC

58 (https://disc.gsfc.nasa.gov/datasets/OMNO2d_003). The Aura satellite was launched by NASA

59 on July 15, 2004, with its overall objective of monitoring the chemistry and dynamics of the

60 atmosphere from the ground to the mesosphere. The OMI is a nadir-viewing charge-coupled

61 device (CCD) spectrometer onboard the Aura satellite, whose observation band is

62 near-UV/visible. We selected the Column Amount $\mathrm{NO}_{2}$ Trop product to calculate the changes in

63 the tropospheric $\mathrm{NO}_{2}$ concentration impacted by the control measures in East Asia, Western

64 Europe and North America (Fig. 2): 


$$
V A=\frac{N_{2}-N_{1}}{N_{1}} \times 100 \%
$$

68 troposphere one month before the lockdown, and $\mathrm{N}_{2}$ is the average $\mathrm{NO}_{2}$ concentration in the

69 troposphere one month after the lockdown.

The data from 1 January 2020 to 3 March 2020, were selected to analyze the variation in

$71 \mathrm{NO}_{2}$ over time in China (Fig. 3). The $\mathrm{NO}_{2}$ satellite data of Italy, Germany, France, the United

72 States, Iran and Switzerland is from the time of the first case in each country to 20 April 2020

73 (Fig. 4). Due to the satellite orbit, default values occur among the daily data that were

74 determined via piecewise linear interpolation over time. Border data from the US Centers for

75 Disease Control and Prevention $\quad$ (CDC)

76 (https://www.cdc.gov/epiinfo/support/downloads/shapefiles.html) were selected to obtain the

77 borders of each country. To remove the influence of weather factors, a 7-day moving average

78 was calculated. To compare the relative changes among the different countries, the data for each

79 country were standardized.

80 The daily total number of new confirmed cases in each country and region was obtained

81 from the Center for Systems Science and Engineering (CSSE) of Johns Hopkins University

82 (https://github.com/CSSEGISandData/COVID-19). The daily total number of new confirmed

83 cases in China was retrieved from the Department Earth System Science of the Tsinghua

84 University shared case database (https://cloud.tsinghua.edu.cn/d/335fd08c06204bc49202/). 
medRxiv preprint doi: https://doi.org/10.1101/2020.05.12.20099804; this version posted July 27, 2020. The copyright holder for this preprint (which was not certified by peer review) is the author/funder, who has granted medRxiv a license to display the preprint in perpetuity.

It is made available under a CC-BY-NC 4.0 International license.

\section{Results analysis}

3.1. A spatial comparison of pollutants before and after lockdown in Hubei Province.

Fig. 1 shows the change in pollutant concentration in Hubei Province one month before and

89 after the closure of major cities severely affected by the epidemic. Compared with before the

90 lockdown, $\mathrm{NO}_{2}$, sulphur dioxide $\left(\mathrm{SO}_{2}\right)$, particulate matter $\left(\mathrm{PM}_{10}\right)$, carbon monoxide $(\mathrm{CO})$ and

$91 \mathrm{PM}_{2.5}$ concentrations all decreased to a certain extent, while $\mathrm{NO}_{2}$ experienced the most notable

92 decrease. Since biomass and coal combustion are major $\mathrm{SO}_{2}$ and $\mathrm{CO}$ sources, they exhibit the

93 lowest rate of improvement (Khalil et al., 1988; Huang et al., 2012). Both the $\mathrm{PM}_{2.5}$ and $\mathrm{PM}_{10}$

94 concentrations decreased to a certain extent (31.2\% and $34.3 \%$, respectively) as a result of the

95 reduction in fugitive dust, particulate matter and important precursors produced by motor

96 vehicles and factories (Huang et al., 2019). The monthly average $\mathrm{PM}_{2.5} / \mathrm{PM}_{10}$ ratio was $0.81(95 \%$

97 confidence interval (CI): 0.76-0.86), so $\mathrm{PM}_{2.5}$ was the main particle pollutant after lockdown.

98 Exhaust emissions contributed only moderately to local levels of the $\mathrm{PM}_{2.5}$ total mass, which

99 were mostly derived from other sources, such as biomass combustion and the remote

100 transmission of secondary particles (Chen et al., 2012). Therefore, the impact of strict traffic

101 control during the lockdown on $\mathrm{PM}_{2.5}$ is not notable, and the spatial difference is large, so $\mathrm{PM}_{2.5}$

102 is not suitable as a city lockdown indicator.

Although the $\mathrm{NO}_{2}$ emissions per vehicle slightly decreased after the upgrading of the

104 quality standards of petroleum products, the notable growth of vehicle ownership increased the 105 proportion of $\mathrm{NO}_{2}$ traffic source emissions, in addition, after the implementation of emission

106 standards for coal-fired power plants, multiple technical improvements greatly controlled the

$107 \mathrm{NO}_{2}$ emissions from coal-fired sources, which all enhanced the correlation between $\mathrm{NO}_{2}$ and city 
medRxiv preprint doi: https://doi.org/10.1101/2020.05.12.20099804; this version posted July 27, 2020. The copyright holder for this preprint (which was not certified by peer review) is the author/funder, who has granted medRxiv a license to display the preprint in perpetuity.

It is made available under a CC-BY-NC 4.0 International license.

108 lockdown effect (Liu et al., 2020). The effect of city closure on $\mathrm{NO}_{2}$ was significantly greater

109 than that on the other pollutants, with an average concentration reduction of approximately $60.3 \%$

110 (95\% CI: 56.8-64.0\%), which can be applied as an environmental indicator of the lockdown

111 effect.

112

113 3.2. Changes of airborne $\mathrm{NO}_{2}$ plummets over COVID-19-hit area after lockdown.

114 In East Asia (Fig. 2a), satellite images show that compared to before the blockade, the total

115 emissions of $\mathrm{NO}_{2}$ in eastern China have significantly decreased by approximately 56.6\%. In

116 South Korea, the monthly $\mathrm{NO}_{2}$ emissions have also been reduced by approximately $18.0 \%$. The

117 local government has implemented the most expansive testing programme and has isolated

118 people infected with the virus without locking down entire cities, and the sharp decrease in $\mathrm{NO}_{2}$

119 may be linked to the reduction in local emissions and pollutant transport from surrounding areas

120 (Han, 2019; Bauwens et al., 2020). Japan has not imposed widespread lockdown policies, and a

$1214.8 \%$ increase in $\mathrm{NO}_{2}$ may be linked to emissions from power generation and industrial

122 processes (Han, 2019). In western Europe (Fig. 2b), the monthly $\mathrm{NO}_{2}$ concentrations have

123 decreased sharply in Italy by $47.5 \%$, particularly in the north $(82.4 \%)$, where the outbreak is the

124 most severe. This could be due to the reduction in road traffic and the decrease in economic

125 activities in the industrial heartland as a result of the widespread lockdown policy (Schiermeier,

126 2020). Other countries such as Germany, Denmark, and Poland also experienced notable

127 reductions. This is consistent with the results of the European Environment Agency (EEA) (EEA,

128 2020). However, in certain areas, such as northern and southern Spain, the $\mathrm{NO}_{2}$ concentration

129 has risen, possibly because of lax closure measures and increased emissions from coal-fired 
medRxiv preprint doi: https://doi.org/10.1101/2020.05.12.20099804; this version posted July 27, 2020. The copyright holder for this preprint (which was not certified by peer review) is the author/funder, who has granted medRxiv a license to display the preprint in perpetuity.

It is made available under a CC-BY-NC 4.0 International license.

130 power plants (Curier et al., 2014). In the United States (Fig. 2c), one month after the lockdown,

131 the overall decline in $\mathrm{NO}_{2}$ is relatively small. The worst affected states, such as New York,

132 Washington and California, still contain areas with increased $\mathrm{NO}_{2}$ concentrations, and the $\mathrm{NO}_{2}$

133 concentration is increasing significantly in the vast midwestern regions that have not yet been

134 locked down.

136 3.3. The temporal evolution of the $\mathrm{NO}_{2}$ concentration and the total number of newly confirmed

137 cases in China.

After the strict city lockdown, the $\mathrm{NO}_{2}$ concentration in the main virus-affected cities in

139 China decreased significantly (Fig. 3). Consistent with the satellite data, the ground monitoring

140 results showed that compared to the conditions before the closure, the monthly average $\mathrm{NO}_{2}$

141 concentration after the lockdown decreased approximately 55.7\% (95\% CI: 51.5-59.6\%). Since

142 the lockdown, the total number of confirmed new cases reaches an inflection point after

143 approximately two weeks (the incubation period of the virus is 14 days), and compared to the

144 period of 1-15 days after the closure, the total number of confirmed new cases in the 16-30 days

145 after the closure has decreased 73.6\% (95\% CI: 64.9-81.1\%). The most significant improvement

146 was recorded in Hangzhou, where the $\mathrm{NO}_{2}$ concentration decreased approximately $68.1 \%$, and

147 the total number of confirmed new cases declined the most. Likewise, Zhengzhou, Changsha,

148 Guangzhou, and Nanchang are good examples. Wuhan, the worst virus-affected area in China,

149 also exhibited a downward trend. The total number of confirmed new cases reached 13,436 on

150 February 12 due to the inclusion of clinically diagnosed cases (Wei et al., 2020), resulting in a 151 new delayed peak in the figure. 
medRxiv preprint doi: https://doi.org/10.1101/2020.05.12.20099804; this version posted July 27, 2020. The copyright holder for this preprint (which was not certified by peer review) is the author/funder, who has granted medRxiv a license to display the preprint in perpetuity.

It is made available under a CC-BY-NC 4.0 International license.

The national emergency response has delayed the spread of the epidemic and greatly limited

153 its range. The suspension of intra-city public transport, the closure of entertainment venues and

154 the banning of public gatherings have been linked to a reduction in the incidence of cases.

155 Studies have shown that before emergency response initiation, the basic case reproduction

156 number $\left(\mathrm{R}_{0}\right)$ is 3.15 , and after intervention measures were implemented in $95 \%$ of all places, the

157 average $\mathrm{R}_{0}$ value has dropped to 0.04 , the total number of actual cases has decreased $96 \%$ (Tian

158 et al., 2020).

160 3.4. The temporal evolution of the $\mathrm{NO}_{2}$ concentration and the total number of newly confirmed

161 cases in the COVID-19-hit areas globally.

After the countries severely affected by COVID-19 implemented strict lockdown measures,

163 satellite data showed a significant decline in $\mathrm{NO}_{2}$ emissions, and the total confirmed new cases

164 decreased after two weeks in most areas (Fig. 4). As a result, the strict lockdown of

165 COVID-19-hit areas other than those in China is also effective and easy to implement to prevent

166 the spread of the virus. The lockdown measures might have already prevented tens of thousands

167 of deaths in Europe (Flaxman et al., 2020). In Italy, where the epidemic is widespread, after the

168 lockdown the $\mathrm{NO}_{2}$ emissions significantly decreased by an average of $36.6 \%$, and the total

169 confirmed new cases reached an inflection point 12 days later, thus verifying that the spread of

170 the virus was effectively controlled. Studies have shown that 38,000 deaths have been averted in

171 this country due to the implemented intervention measures (Flaxman et al., 2020). The

172 occurrence time of the inflection point is mainly related to the magnitude of $\mathrm{NO}_{2}$ decline. In

173 France, $\mathrm{NO}_{2}$ declined less $(27.1 \%)$, and the time for the total number of confirmed new cases to 
medRxiv preprint doi: https://doi.org/10.1101/2020.05.12.20099804; this version posted July 27, 2020. The copyright holder for this preprint (which was not certified by peer review) is the author/funder, who has granted medRxiv a license to display the preprint in perpetuity.

It is made available under a CC-BY-NC 4.0 International license.

174 reach an inflection point was delayed. In Germany, the $\mathrm{NO}_{2}$ emissions decreased the most, by

$17554.7 \%$, and the total number of confirmed new cases reached an inflection point within 8 days

176 after lockdown, which occurred earlier than in other countries. For Iran and Switzerland, due to

177 the relatively low number of confirmed cases, with the decline of $\mathrm{NO}_{2}$ after the strict control,

178 confirmed new cases also reached the inflection point earlier. In the the worst-affected states,

179 United States, $\mathrm{NO}_{2}$ emissions decreased by an average of $43.1 \%$ in New York, Washington and

180 California, and the total confirmed new cases dropped significantly, showing signs of easing.

182 3.5. The results after epidemic control in the COVID-19-hit areas globally.

184 cases dropped by more than $50 \%$ within 30 days and $\mathrm{NO}_{2}$ declined significantly in most

185 countries (Figure 5a). Especially in most countries in Europe and the Western Pacific region, the

186 number of newly confirmed cases dropped more markedly, with an average drop of more than

$18760 \%$. The newly confirmed cases in Ireland, Austria, Japan fell by more than 80\%. The reduction

188 in the number of newly confirmed cases is closely related to the intensity of interventions, and

$189 \mathrm{NO}_{2}$ can quantify the effects and intensity of interventions. Among the top 50 countries with the

190 cumulative number of confirmed cases, the stricter the control measures, the higher the rate of

191 decrease in newly confirmed cases (Figure 5b). If the $\mathrm{NO}_{2}$ reduction rate is only about $25 \%$, the

192 control effect of government intervention measures on the epidemic situation is not significant

193 (Figure 5b). 
medRxiv preprint doi: https://doi.org/10.1101/2020.05.12.20099804; this version posted July 27, 2020. The copyright holder for this preprint (which was not certified by peer review) is the author/funder, who has granted medRxiv a license to display the preprint in perpetuity.

It is made available under a CC-BY-NC 4.0 International license .

In Germany, when large public events were canceled, the spreading rate $(\lambda)$ dropped from

196 Only when a contact ban was imposed by government authorities, $\lambda$ dropped to 0.09 , which is

197 lower than the recovery speed, and the exponential growth of new cases turned to decline

198 (Dehning et al., 2020). In Wuhan, China, due to the strict lockdown, the estimated effective

199 reproduction number Rt fell immediately after reaching a peak of 3.82 on January 24 and fell

200 below 1.0 on February 6, 2020 ( $\mathrm{NO}_{2}$ mutation time) (Pan et al., 2020). In summary, stringent

201 interventions help to reduce newly confirmed cases earlier and more rapidly. $\mathrm{NO}_{2}$ can be used as

202 an environmental indicator for quantitative research to assess the efficacy and timing of

203 non-pharmacological interventions to guide current and future responses to global pandemics.

\section{4. Discussion}

Urbanization and rapid transportation system development accelerate the spread of

207 COVID-19, and only strict containment measures can effectively prevent a second and third

208 outbreak (Huang et al., 2020b; Huang et al, 2020c). The $\mathrm{NO}_{2}$ concentration can be considered an

209 inexpensive indicator of virus transmission control. As a result of strict control measures and the

210 rapid implementation of first-level emergency measures, the $\mathrm{NO}_{2}$ emissions and total number

211 confirmed new cases significantly decreased in China, especially in the strictly controlled cities.

212 In many European countries, a strict lockdown is also effective and easy to do to prevent the

213 spread of the virus. But there are also areas such as southern and northern Spain and parts of the

214 United States where the $\mathrm{NO}_{2}$ level has increased. 
medRxiv preprint doi: https://doi.org/10.1101/2020.05.12.20099804; this version posted July 27, 2020. The copyright holder for this preprint (which was not certified by peer review) is the author/funder, who has granted medRxiv a license to display the preprint in perpetuity. It is made available under a CC-BY-NC 4.0 International license.

Studies have shown that the likelihood of fewer cases in the gradual multi-stage policy is

216 zero, and that such a policy decision implies that the government is willing to risk an increase in

217 COVID19 cases and deaths in exchange for decreased economic and isolation impacts, which

218 may not be desirable from an objective point of view (Karnon, 2020). Although the immediate

219 adoption of a lockdown policy may lead to many people being adversely affected financially, in

220 the short term, the number of new confirmed cases will decline approximately 15 days after

221 policy implementation, and an earlier decline can occur with stricter lockdown measures.

222 International guidance supports a range of mandatory social isolation measures, extensive case

223 detection, and isolation and contact tracing. Compliance with quarantine directives is absolutely

224 critical to saving lives, protecting the most vulnerable in society, and ensuring that the national

225 security system can cope and care for the sick (Iacobucci, 2020). In such cases, an immediate

226 lockdown policy may be preferred, and $\mathrm{NO}_{2}$, as an environmental indicator of virus control, can

227 help managers implement effective control measured to curb the spread of COVID-19. In

228 addition, $\mathrm{NO}_{2}$ evolution can be used to predict the COVID-19 newly confirmed cases, using the

229 local $\mathrm{NO}_{2}$ change rate to reflect the effects of the control measures of governments in various

230 countries. For details, please refer to the Global Prediction System of the COVID-19 Pandemic

231 (http://covid-19.1zu.edu.cn).

\section{5. Conclusion}

By combining historical COVID-19 data, $\mathrm{NO}_{2}$ satellite data and government control

235 measures, we analyzed the quantification and control effects of epidemic intervention measures.

236 The inflection point and reduction rate of newly confirmed cases are closely related to the time 
237 and intensity of epidemic control measures. The decline rate of $\mathrm{NO}_{2}$ is influenced by the

238 emission characteristics of each country, on the other hand, it is largely related to the intensity

239 and implementation effect of control measures. Therefore, $\mathrm{NO}_{2}$ can be used as an environmental

240 indicator to quantify the effectiveness and intensity of interventions and can be incorporated into

241 assessments of the implementation of existing outbreak control measures in countries and into

242 prediction of future scenarios and case numbers. In addition, $\mathrm{NO}_{2}$ would help provide

243 policymakers with information on strengthening, easing and selecting appropriate measures to

244 contain COVID-19 and other future global pandemics. 
medRxiv preprint doi: https://doi.org/10.1101/2020.05.12.20099804; this version posted July 27, 2020. The copyright holder for this preprint (which was not certified by peer review) is the author/funder, who has granted medRxiv a license to display the preprint in perpetuity.

It is made available under a CC-BY-NC 4.0 International license .

Baccini L, Brodeur A. Explaining governors' response to the COVID-19 pandemic in the United States. 2020.

Bauwens M, Compernolle S, Stavrakou T, Müller JF, Van Gent J, Eskes H, Levelt PF, Vander R,Veefkind JP, Vlietinck J, Yu H, Zehner C. Impact of coronavirus outbreak on $\mathrm{NO}_{2}$ pollution assessed using TROPOMI and OMI observations. Geophys Res Lett 2020; 47.

Brnnum-Hansen H, Bender AM, Andersen ZJ, Sørensen J, Bønløkke JH, Boshuizen H, Becker T, Diderichsen F, Loft S. Assessment of impact of traffic-related air pollution on morbidity and mortality in Copenhagen Municipality and the health gain of reduced exposure. Environ Int 2018; 121: 973-980.

Chen Y, Liu Q, Geng F, Zhang H, Cai C, Xu T, Ma X, Li H. Vertical distribution of optical and micro-physical properties of ambient aerosols during dry haze periods in Shanghai. Atmos Environ 2012; 50: 50-59.

Clougherty JE, Kheirbek I, Eisl HM, Ross Z, Pezeshki G, Gorczynski JE, Johnson S, Markowitz S, Kass D, Matte T. Intra-urban spatial variability in wintertime street-level concentrations of multiple combustion-related air pollutants: The New York City Community Air Survey (NYCCAS). J Expo Sci Env Epid 2013; 23: 232-240.

Curier RL, Kranenburg R, Segers AJS, Timmermans RMA, Schaap M. Synergistic use of OMI $\mathrm{NO}_{2}$ tropospheric columns and LOTOS-EUROS to evaluate the NOx emission trends across Europe. Remote Sens of Environ 2014; 149: 58-69.

Dehning J, Zierenberg J, Spitzner FP, Wibral M, Neto JP, Wilczek M, Priesemann V. Inferring change points in the spread of COVID-19 reveals the effectiveness of interventions. Science 2020.

Fan X, Dawson J, Chen M, Qiu C, Khalizov A. Thermal stability of particle-phase monoethanolamine salts. Environ Sci Tech 2018; 52: 2409-2417.

EEA. Air pollution goes down as Europe takes hard measures to combat coronavirus. 2020.

Flaxman S, Mishra S, Gandy A. Estimating the number of infections and the impact of nonpharmaceutical interventions on COVID-19 in 11 European countries. Imperial College COVID-19 Response Team 2020. 
medRxiv preprint doi: https://doi.org/10.1101/2020.05.12.20099804; this version posted July 27, 2020. The copyright holder for this preprint (which was not certified by peer review) is the author/funder, who has granted medRxiv a license to display the preprint in perpetuity. It is made available under a CC-BY-NC 4.0 International license .

Han KM. Temporal Analysis of OMI-Observed Tropospheric $\mathrm{NO}_{2}$ Columns over East Asia during 2006-2015. Atomos 2019; 10: 658.

Huang C, Wang Y, Li X, Ren L, Zhao J, Hu Y, Zhang L, Fan G, Xu J, Gu X, Cheng Z, Yu T, Xia J, Wei Y, Wu W, Xie X, Yin W, Li H, Liu M, Xiao Y, Gao H, Guo L, Xie J, Wang G, Jiang R, Gao Z, Jin Q, Wang J, Cao B. Clinical features of patients infected with 2019 novel coronavirus in Wuhan, China. Lancet (London, England) 2020a.

Huang F, Zhou J, Chen N, Li Y, Wu S. Chemical characteristics and source apportionment of $\mathrm{PM}_{2.5}$ in Wuhan, China. J Atmos Chem 2019; 76: 245-262.

Huang J, Liu X, Zhang Li, Yang K, Chen Y, Huang Z, Liu C, Lian X, Wang D. The amplified second outbreaks of global COVID-19 pandemic. medRxiv $2020 \mathrm{~b}$.

Huang Q, Cheng S, Perozzi RE. Use of a MM5-CAMx-PSAT Modeling System to Study $\mathrm{SO}_{2}$ Source Apportionment in the Beijing Metropolitan Region. Environ Model Assess 2012; 17: 527-538.

Huang Z, Huang J, Gu Q, Du P, Liang H, Dong Q. Optimal temperature zone for the dispersal of COVID-19. Sci Total Environ 2020c: 139487.

Iacobucci G. Covid-19: UK lockdown is "crucial" to saving lives, say doctors and scientists. Bmj-Brit Med J 2020; 368.

Johansson C, Lovenheim B, Schantz P, Wahlgren L, Almstrom P, Markstedt A, Stromgren M, Forsberg B, Sommar J. Impacts on air pollution and health by changing commuting from car to bicycle. Sci Total Environ 2017; 584: 55-63.

Karnon J. A Simple Decision Analysis of a Mandatory Lockdown Response to the COVID-19 Pandemic. Appl health econ hea 2020; 18: 329-331.

Khalil MAK, Rasmussen, R. A. Carbon Monoxide in an Urban Environment: Application of a Receptor Model for Source Apportionment. Japca 1988; 38: 901-906.

Kim Y, Guldmann JM. Land-use regression panel models of $\mathrm{NO}_{2}$ concentrations in Seoul, Korea. Atmos Environ 2015; 107: 364-373.

Legido-Quigley H, Mateos-Garcia JT, Campos VR, Gea-Sanchez M, Muntaner C, McKee M. The resilience of the Spanish health system against the COVID-19 pandemic. Lancet Public heal 2020; 5: e251-e252. 
medRxiv preprint doi: https://doi.org/10.1101/2020.05.12.20099804; this version posted July 27, 2020. The copyright holder for this preprint (which was not certified by peer review) is the author/funder, who has granted medRxiv a license to display the preprint in perpetuity. It is made available under a CC-BY-NC 4.0 International license.

Li Q, Guan X, Wu P, Wang X, Zhou L, Tong Y, Ren R, Kathy SML, Eric HYL, Jessica YW, Xing X, Xiang N. Early Transmission Dynamics in Wuhan, China, of Novel Coronavirus -Infected Pneumonia. New Engl J Med 2020.

Lian X, Huang J, Huang R, Liu C, Wang L, Zhang T. Impact of city lockdown on the air quality of COVID-19-hit of Wuhan city. Sci Total Environ 2020: 140556.

Liu D, Deng Q, Ren Z, Zhou Z, Song Z, Huang J, Hu R. Variation trends and principal component analysis of nitrogen oxide emissions from motor vehicles in Wuhan City from 2012 to 2017. Sci Total Environ 2020; 704: 134987.

Pan A, Liu L, Wang C, Guo H, Hao X, Wang Q, Huang J, He N, Yu H, Lin X. Association of public health interventions with the epidemiology of the COVID-19 outbreak in Wuhan, China. JAMA 2020; 323: 1915-1923.

Paterlini M. Lockdown in Italy: personal stories of doing science during the COVID-19 quarantine. Nature 2020.

Schiermeier Q. Why pollution is plummeting in some cities - but not others. Nature 2020; 580: 313.

Cyranoski D, Silver A. Wuhan scientists: What it's like to be on lockdown. Nature 2020.

Tessum MW, Larson T, Gould TR, Simpson CD, Yost MG, Vedal S. Mobile and Fixed-Site Measurements To Identify Spatial Distributions of Traffic-Related Pollution Sources in Los Angeles. Environ Sci Tech 2018; 52: 2844-2853.

Tian H, Liu Y, Li Y, Wu C, Chen B, Kraemer MUG, Li B, Cai J, Xu B, Yang Q. An investigation of transmission control measures during the first 50 days of the COVID-19 epidemic in China. Science 2020; 368: 638-642.

Wei Y, Wei L, Jiang Y, Shen S, Zhao Y, Hao Y, Du Z, Tang J, Zhang Z, Jiang Q. Implementation of Clinical Diagnostic Criteria and Universal Symptom Survey Contributed to Lower Magnitude and Faster Resolution of the COVID-19 Epidemic in Wuhan. Engineering 2020.

Wu JT, Leung K, Leung GM. Nowcasting and forecasting the potential domestic and international spread of the 2019-nCoV outbreak originating in Wuhan, China: a modelling study. Lancet (London, England) 2020.

Yuan B, Hu W, Shao M, Wang M, Chen W, Lu S, Zeng L, Hu M. VOC emissions, evolutions and contributions to SOA formation at a receptor site in eastern China. Atmos Chem Phys 2013; 13: 8815-8832. 
medRxiv preprint doi: https://doi.org/10.1101/2020.05.12.20099804; this version posted July 27, 2020. The copyright holder for this preprint (which was not certified by peer review) is the author/funder, who has granted medRxiv a license to display the preprint in perpetuity.

It is made available under a CC-BY-NC 4.0 International license.

336 Zhou Z, Tan Q, Liu H, Deng Y, Wu K, Liu C, Zhou X. Emission characteristics and high-resolution spatial and temporal distribution of pollutants from motor vehicles in Chengdu, China. Atmos Pollut Res 2019; 10: 749-75. 


\section{Acknowledgements}

343 This work was jointly supported by the National Science Foundation of China (41521004)

344 and the Gansu Provincial Special Fund Project for Guiding Scientific and Technological 345 Innovation and Development (Grant No. 2019ZX-06). The authors acknowledge the China 346 National Environmental Monitoring Centre for providing the datasets. http://www.cnemc.cn/.

Competing financial interests: The authors declare no competing financial interests.

Graphics software

$352 \quad$ All maps and plots were produced using licensed. 


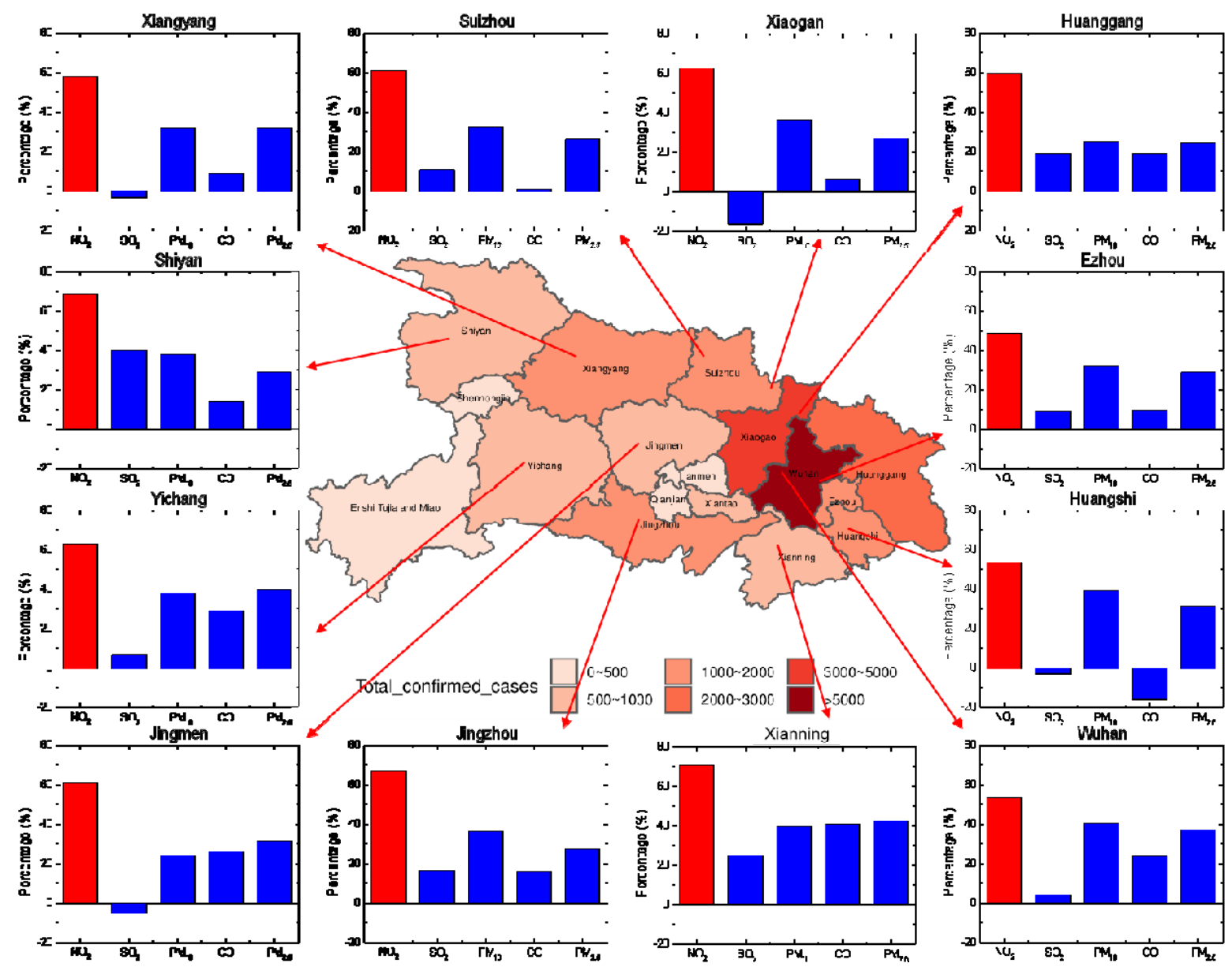

354 Fig. 1 The improvement rate of the major pollutants and the distribution of the accumulated epidemic numbers in each city of Hubei Province after the lockdown. One month after the blockade (23 February 2020), the cumulative number of confirmed cases ranged from 0-46607 (Wuhan), as indicated by the colour scale. The monthly mean improvement rate of $\mathrm{NO}_{2}, \mathrm{SO}_{2}, \mathrm{PM}_{10}, \mathrm{CO}$ and $\mathrm{PM}_{2.5}$ after the lockdown in the worst virus-affected areas is shown in the histogram, with $\mathrm{SO}_{2}, \mathrm{PM}_{10}, \mathrm{CO}$ and $\mathrm{PM}_{2.5}$ indicated with blue columns, and $\mathrm{NO}_{2}$ indicated with red columns. Red columns $\left(\mathrm{NO}_{2}\right)$ are significantly higher than the others, so it can characterize the locking measures. 


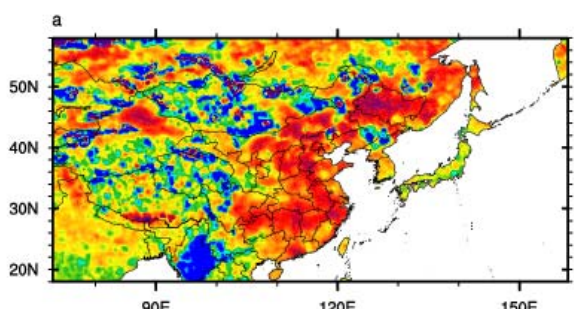

$90 \mathrm{E}$
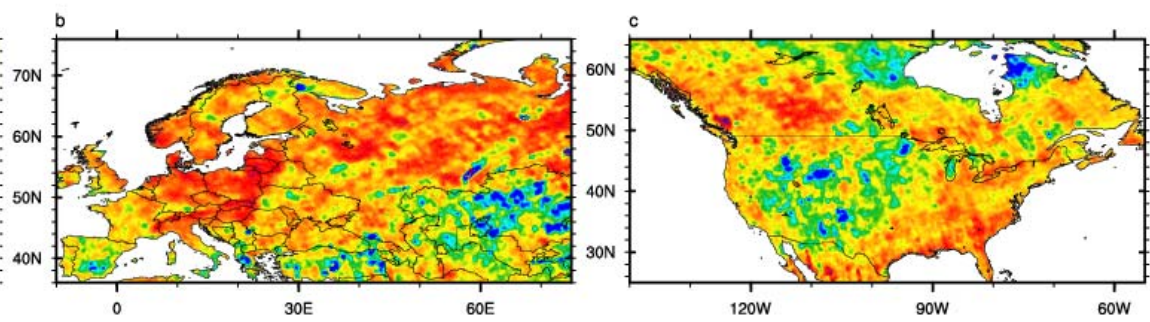

$\begin{array}{llllllllllllll}-100 & -90 & -80 & -70 & -60 & -50 & -40 & -30 & -20 & -10 & 0 & 10 & 20 & 30\end{array}$

90W

363 Fig. 2 The relative variation in the monthly average tropospheric $\mathrm{NO}_{2}$ concentration before

364 and after the lockdown. a, Relative variation in East Asia. b, Relative variation in Western 365 Europe. c, Relative variation in North America. The colour table represents the relative 366 percentage of the monthly average change in $\mathrm{NO}_{2}$ after the locksown compared to the before. 367 The red areas indicate that the $\mathrm{NO}_{2}$ concentration decreased, and the blue areas indicate that the $368 \mathrm{NO}_{2}$ concentration increased. The lockdown in East Asia, Western Europe and North America 369 began on January 23, March 10, and March 16, respectively. Source: Analysis of data from the 370 NASA Ozone Monitoring Instrument (OMI). 
medRxiv preprint doi: https://doi.org/10.1101/2020.05.12.20099804; this version posted July 27, 2020. The copyright holder for this preprint (which was not certified by peer review) is the author/funder, who has granted medRxiv a license to display the preprint in perpetuity.

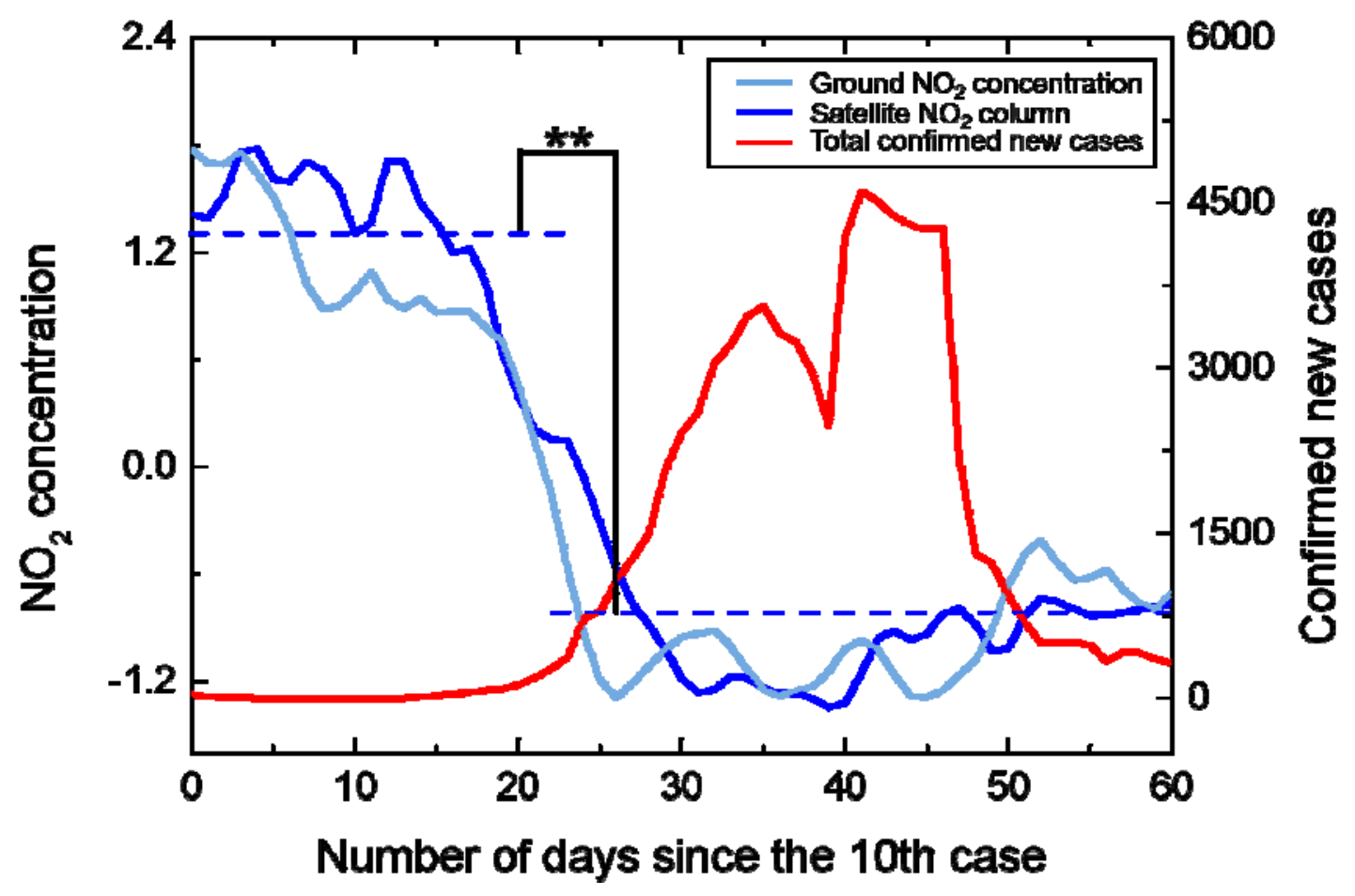

372

373 Fig. 3 Temporal variation in the $\mathrm{NO}_{2}$ concentration and number of new cases in China. The 374 standardized 7-day smooth data of $\mathrm{NO}_{2}$ is represented by blue lines, with satellite observations in 375 dark blue and ground observations in light blue. The dotted line indicates the average value of $376 \mathrm{NO}_{2}$ before and after the blockade. The 7-day smooth data of total confirmed new cases is 377 indicated by red lines. $* *$ indicates significant difference at the 0.01 level (bilateral), and * 378 indicates significant difference at the 0.05 level (bilateral). Starting from the lockdown, the $\mathrm{NO}_{2}$ 379 concentration dropped significantly, and the number of new cases also showed a downward trend 380 within two weeks. 

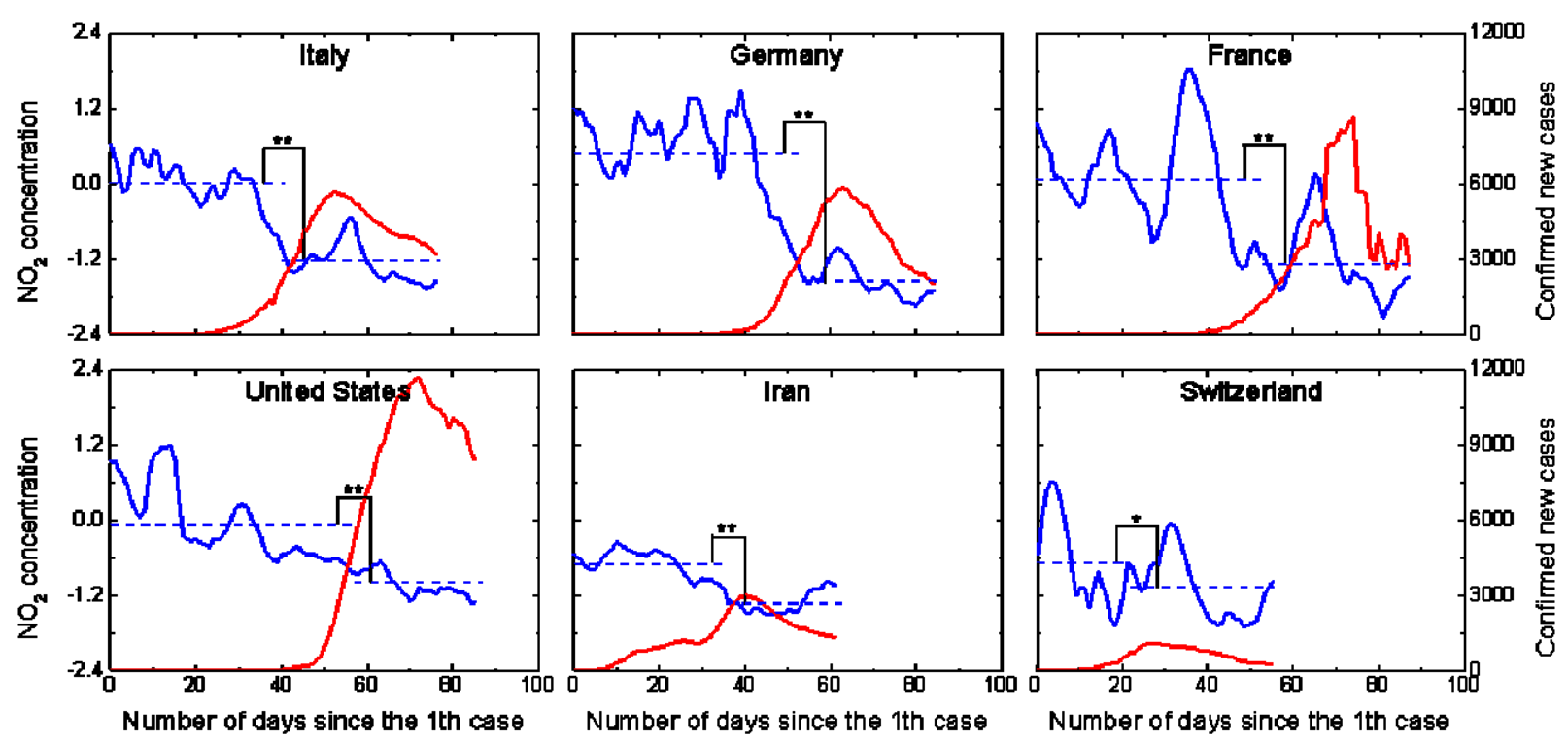

Total confirmed new cases

Fig. 4 Temporal variation in the $\mathrm{NO}_{2}$ concentration and number of new cases in the COVID-19-hit areas. Italy, Germany, France, the United States, Iran and Switzerland were selected as the representatives of COVID-19-hit areas. New York, Washington and California were selected as the representatives of the United States. From the time of the first case in each country to 20 April 2020, the standardized 7-day smooth satellite data of $\mathrm{NO}_{2}$ is represented by the blue line. The dotted line indicates the average value of $\mathrm{NO}_{2}$ before and after the blockade. The 7-day smooth data of total confirmed new cases is indicated by red line. ${ }^{* *}$ indicates significant difference at the 0.01 level (bilateral), and * indicates significant difference at the 0.05 level (bilateral). The $\mathrm{NO}_{2}$ in major countries showed a downward trend. The total confirmed 

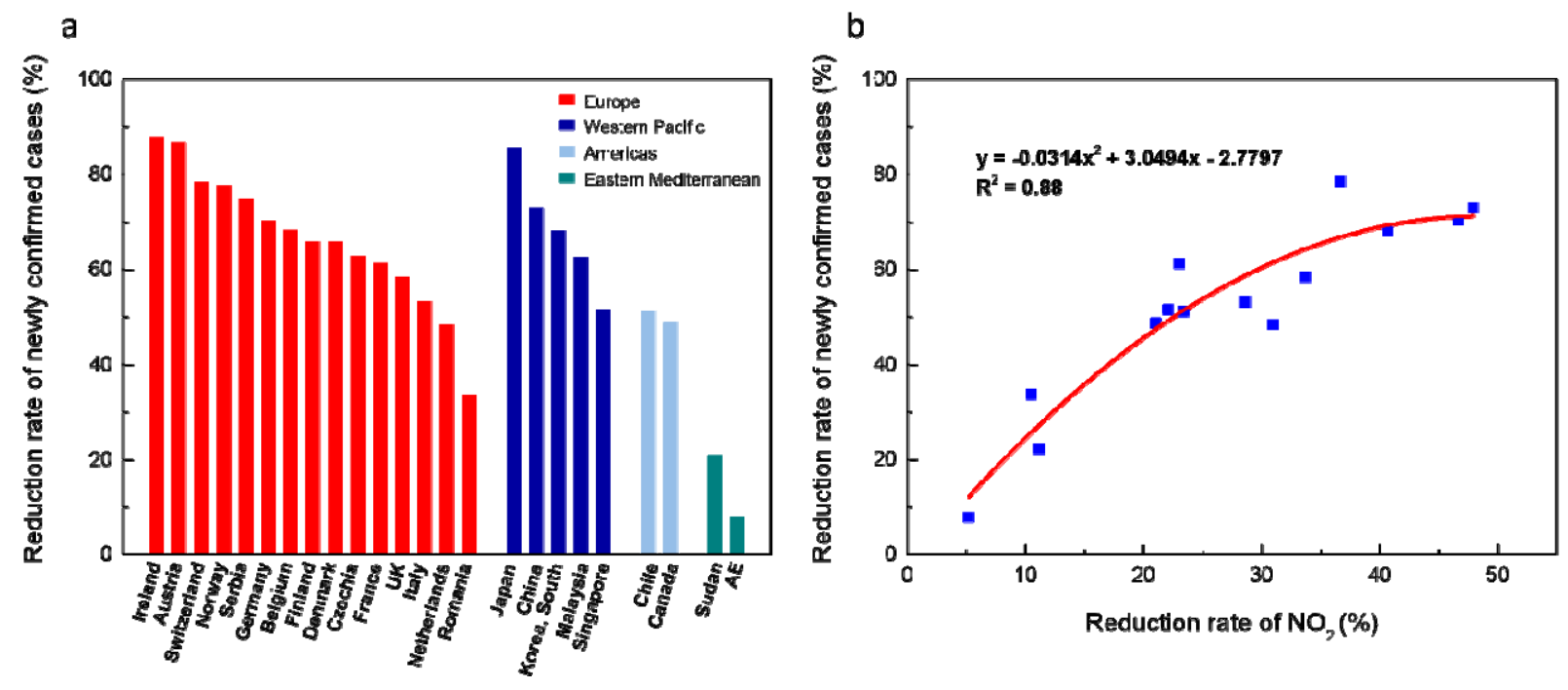

Fig 5. The results of strict epidemic control measures. a, The reduction rate of new confirmed cases within 30 days at the $\mathrm{NO}_{2}$ mutation point. Red represents Europe, dark blue represents Western Pacific, light blue represents Americas, and green represents Eastern Mediterranean. b, Changes in the rate of decline in $\mathrm{NO}_{2}$ and the reduction rate of newly confirmed cases after the implementation of strict epidemic control measures. 